\title{
Analysis of Heavy Metal Sources and Health Risk Assessment of Typical Coal Mine Collapsed Lakes in Huaibei Coalfield, Anhui Province, China
}

\author{
Jun Li ${ }^{1,2}$, Herong Gui ${ }^{2 *}$, Rongjie $\mathrm{Hu}^{2,4}$, Luwang Chen ${ }^{1}$, Yuting Xia ${ }^{2,3}$, \\ Hongxia Fan ${ }^{2,3}$, Hao Yu ${ }^{2,3}$, Meichen Wang ${ }^{2,3}$
}

${ }^{1}$ School of Resources and Environmental Engineering, Hefei University of Technology, Hefei, Anhui, China; ${ }^{2}$ National Engineering Research Center of Coal Mine Water Hazard Control, Suzhou University, Suzhou, Anhui, China

${ }^{3}$ School of Earth and Environment, Anhui University of Science and Technology, Huainan, Anhui, China ${ }^{4}$ Wanbei Coal-Electricity Group Co. Ltd, Suzhou, Anhui, China

Received: 19 October 2019

Accepted: 6 November 2019

\begin{abstract}
Heavy metals in the collapsed lake of Zhuxianzhuang Mine in the typical coal mine of Huaibei Coalfield were selected as the research object. Differences, sources and human health risks of heavy metals such as $\mathrm{Cu}, \mathrm{Cd}, \mathrm{Cr}, \mathrm{Ni}, \mathrm{Pb}, \mathrm{V}, \mathrm{Zn}$ and $\mathrm{Mn}$ in four seasons of lake water were analyzed. Among them, the content of $\mathrm{V}$ element was the highest in all four seasons $(1.80 \sim 7.04 \mathrm{mg} / \mathrm{l})$, while the content of $\mathrm{Cd}$ was the lowest $(0.03 \sim 1.92 \mathrm{mg} / \mathrm{l})$. In addition, the elements of the super background value are: $\mathrm{V}, \mathrm{Ni}, \mathrm{Cu}$, and $\mathrm{Cr}$, wherein the $\mathrm{V}$ content exceeds the background value multiple of 4.3 to 12.93 . Principal component analysis (PCA) results show that the three principal components share $81.6 \%$ of the variance contribution rate. Finally, the results of lake water health risk assessment showed that the risk of non-carcinogenicity of 8 heavy metals was: $\mathrm{Cu}>\mathrm{Cd}>\mathrm{Cr}>\mathrm{Ni}>\mathrm{Pb}>\mathrm{V}>\mathrm{Zn}>\mathrm{Mn}$. The $\mathrm{Cr}$ element is the main carcinogenic risk element in the lake water of the study area, and the risk value is concentrated at 1.16E-08 7.54E-07. Among the exposed population, the hazard index (HI) of Mn was 49.21 times that of adults. In general, the hazard index value is $<1$, and the cancer risk is within acceptable levels (1E-06). But from the perspective of public health and safety, we need to maintain further observation and research on these elements.
\end{abstract}

Keywords: coal mine collapsed lake, heavy metal element, health risk assessment, Huaibei Coalfield

\section{Introduction}

Coal mining worldwide is deteriorating the local mining environment in different ways [1-2]. Ground

*e-mail: guiherong@163.com

subsidence, air pollution, vegetation pollution and water pollution have become important environmental threats caused by coal mining activities [3-4]. Among them, environmental damage caused by ground subsidence is one of the problems to be solved [5-6]. As of 2011, the ground subsidence area caused by coal mining activities in China reached $8000 \mathrm{~km}^{2}$ [7]. Large-scale ground subsidence forms a coal mine collapsed lake under the 
recharge of atmospheric precipitation, surface water and shallow groundwater [8]. Therefore, the collapsed lake is a special surface water body formed by the nonartificial excavation unique to the mining area, and the current status of the collapsed lake water environment quality has received extensive attention [9]. With the development of ecotoxicological methods such as bioassays, the pollution status of heavy metal elements with toxic accumulation and long-lasting properties on natural waters is severe [10-12]. In the current research situation, the main research contents of coal mining subsidence lakes focus on water quality assessment, water body repair, and water management. For example, Chen (2019) and other selected heavy metal elements in six collapsed waters of Huainan coalfield for health risk assessment [13]; Xie et al. (2013) analyzed the water quality of the collapsed waters in Huaibei, and proposed a variety of ecological restoration methods. However, such research is lacking in the Huaibei coalfield where the collapsed lake area is relatively wide (about $300 \mathrm{~km}^{2}$ ) [14].

In Huaibei coalfield, the Zhuxianzhuang coal mine has a long history of mining. Lake water body formed 25 to 35 years ago, the water depth is $3 \sim 7 \mathrm{~m}$, and the environmental geochemical characteristics of heavy metal elements are typical. To this end, the two collapsed lakes of Zhuxianzhuang Mine in Huaibei Coalfield were selected as the research object. The research objectives include: (1) demonstrate the distribution characteristics of heavy metal elements in the two water bodies in the four seasons, (2) explain the source of heavy metal elements in water, (3) calculate the health risk value of heavy metal elements for adults and children, and (4) provide reference for the utilization of the water body in the collapsed lake of Huaibei coalfield.

\section{Methods and Materials}

\section{Study Area and Sampling}

Zhuxianzhuang Mine is situated in Suzhou City, northern Anhui Province, and was put into operation in April 1983. Mine field range: $117^{\circ} 05^{\prime} 37.6^{\prime \prime} \mathrm{E} \sim 117^{\circ} 09^{\prime} 23^{\prime \prime} \mathrm{E}$, $33^{\circ} 33^{\prime} 31.4^{\prime \prime} \mathrm{N} \sim 33^{\circ} 39^{\prime} 37.6^{\prime \prime} \mathrm{N}$. The area of the minefield is $26.3 \mathrm{~km}^{2}$, and the current annual coal production capacity is 2.45 million tons. After more than 30 years of mining, the collapsed area is about $11 \mathrm{~km}^{2}$ [15]. In this study, the collapsed lakes are formed on the surface of the second and fourth mining areas, respectively. In order to facilitate the analysis, according to the collapsed time, two lakes are named as collapsed lake-I $(C L-I)$ and the collapsed lake-II $(C L-I I)$. There are many fish culture zones and phytoplankton growth in the collapsed lake. In addition, many pieces of coal gangue and fly ash are accumulated along the lakeshore. The study area and sampling location are shown in Fig. 1.

Lake water sampling was implemented according to Standard of Surface Water and Sewage Detection Technology HJ/T91-2002 [16]. The sampling was divided into four stages: summer (July 2017), autumn (October 2017), winter (January 2018), and spring (May 2018), and the sampling period was 1 year. Before sampling, the raw water at $0.5 \mathrm{~m}$ below the water surface was cleaned and the polyethylene

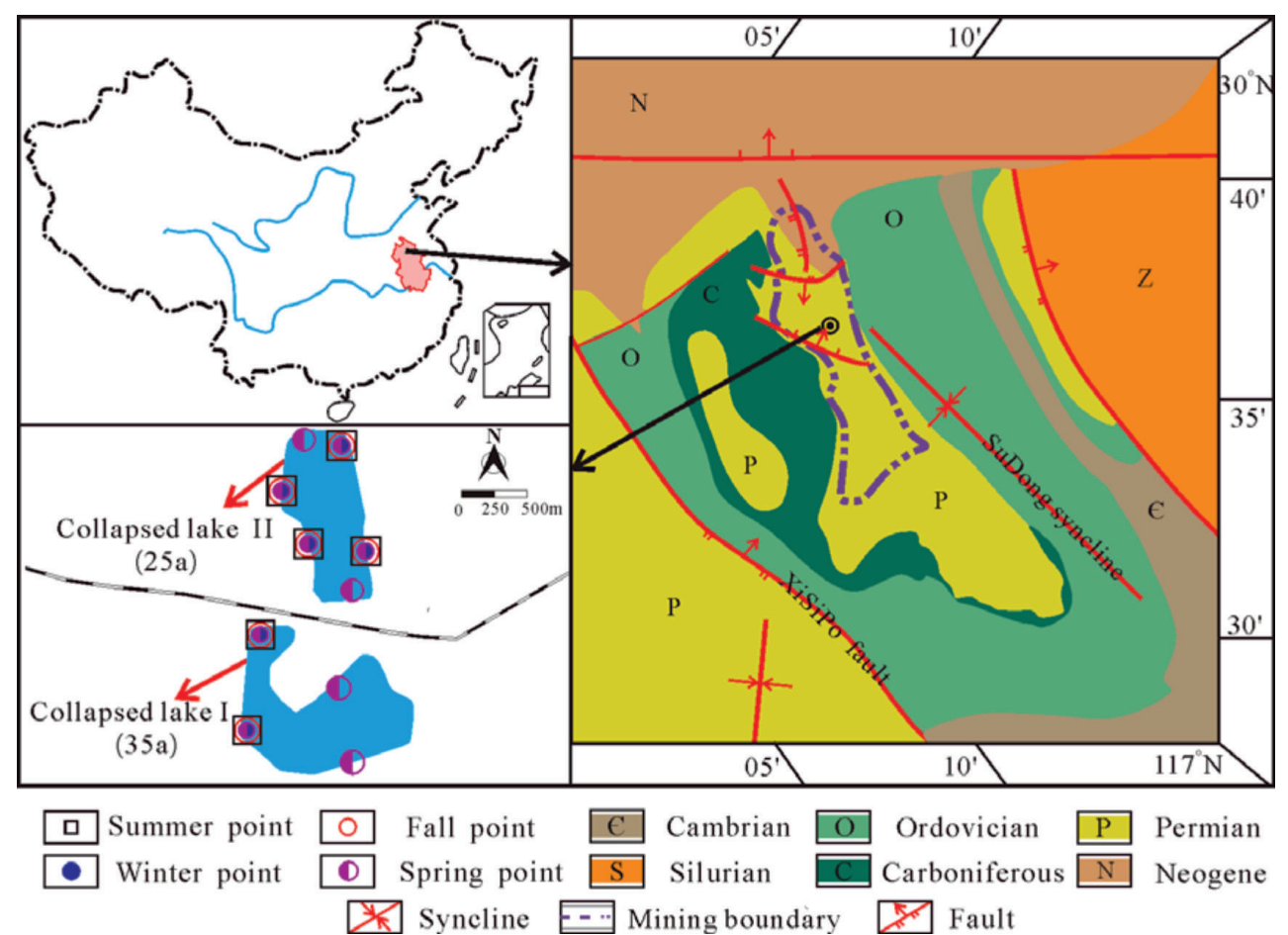

Fig. 1. Map of the study area and sampling locations. 
sampling bottle $(2.5 \mathrm{~L})$ was loaded three times before sampling. After retrieval, it was filtered by $0.45 \mathrm{~m}$ microporous membrane and adjusted by high-grade pure concentrated nitric acid for $\mathrm{pH}$ reserve. A total of 28 samples were taken from the two lakes, and the sampling points were positioned using handheld GPS. After collecting freshwater samples, we added nitric acid of guaranteed reagent $(65-68 \%)$ reagent to digest a small amount of organic matter. Then we added nitric acid $(2 \%)$ to maintain an acidic environment for testing an inductively coupled plasma mass spectrometer (ICPMS) (Agilent 7500cx) selected to test the elements of $\mathrm{V}, \mathrm{Cr}, \mathrm{Mn}, \mathrm{Ni}, \mathrm{Cu}, \mathrm{Zn}, \mathrm{Cd}$ and $\mathrm{Pb}$. In order to ensure the authenticity of the experimental data, the average values of the three experimental data were taken as the experimental results, and the error of the experimental analysis was controlled to within 5\%. The test data of the standard sample was very consistent with the authentication value, which shows the accuracy of the test.

\section{Research Method}

\section{Principal Component Analysis}

PCA is a method for characterizing the information carried by all variables with a small number of indicators according to actual needs and used for heavy metal source analysis in this study [17]. Before the analysis, in order to compress the data scale and make the data more stable, all variables in the original data were subjected to logarithmic transformation that can be calculated according to Equation (1). Software analysis was done using statistical product and service solutions (SPSS).

$$
y_{i j}=\log c_{i j}-\frac{1}{p} \sum_{i=l}^{p} \log c_{i j}(i=1,2 \ldots, m, j=1,2 \ldots, p)
$$

...where $c_{i j}$ was the raw measurement of the $j$ th indicator of the $i$ th water sample $(\mathrm{mg} / \mathrm{L})$, and $y_{i j}$ was the $x_{i j}$ after the logarithmization process.

\section{Human Health Risk Assessment}

Heavy metals affected human health by causing cancer and non-cancer diseases in human organs [1819]. Routes entering the human body were dermal absorption, direct intake and inhalation [20-21]. Combined with the actual situation of this study, there were multiple fish culture areas in the waters and they were not used as local drinking water sources. Therefore, the risk of human health caused by heavy metal elements passing through the food chain was the most common exposure route [22].
Based on the risk criteria recommended by the United States Environmental Protection Agency (USEPA) 2004 [23], the daily exposure dose $\left(\mathrm{ADD}_{\text {ingestion }}\right)$ of food ingested in water was calculated according to formula (2):

$$
A D D_{\text {ingestion }}=\frac{C_{i} \times I_{R} \times B C F \times E F \times E D}{B_{W} \times A T}
$$

...where $C_{i}$ denoted the test value of heavy metal elements in each water sample $(\mu \mathrm{g} / \mathrm{L})$ and $I_{R}$ denoted the daily average fish consumption of the human body. The average daily fish consumption of an adult was $0.0065 \mathrm{~kg}$ [24]. The average daily fish consumption of children was $0.0019 \mathrm{~kg}$ [25]; $B C F$ denoted fish bioaccumulation coefficient $(\mathrm{mg} / \mathrm{kg} / \mathrm{d})$, where 2.7 for $\mathrm{V}, 16$ for $\mathrm{Cr}, 47$ for $\mathrm{Ni}, 200$ for $\mathrm{Cu}, 47$ for $\mathrm{Zn}, 81$ for $\mathrm{Cd}$, 49 for $\mathrm{Pb}$ [26], and 0.34 for $\mathrm{Mn}$ [27]; $E F$ was the exposure frequency (d/a) and the value was 350 ; $E D$ was the exposure period (a), adult was 30 [28], and child was 6 [29]; $B w$ was the average body weight $(\mathrm{kg})$, the average adult weight was 56.8, and the average child weight was 15.9; $A T$ was the average time for carcinogenic or non-carcinogenic (d), the average time for carcinogenesis was 25550 [28], the average time for non-cancer in adults was 10950, and the average time for non-carcinogenesis in children was 2190 [29].

In this study, chemical carcinogens $\mathrm{Cd}$ and $\mathrm{Cr}$ were selected for carcinogenic health risk assessment models [30-31], and chemical carcinogens also had non-carcinogenic effects [32-33]. Therefore, chemical non-carcinogenic elements $(\mathrm{Cr}, \mathrm{Cd}, \mathrm{Cu}, \mathrm{V}, \mathrm{Zn}, \mathrm{Mn}$, $\mathrm{Ni}, \mathrm{Pb}$ ) were selected by non-carcinogenic health risk assessment models. The calculation formulas of the two models were as shown in Equations (3), (4), and (5):

$$
H Q_{\text {ingestion }}=\frac{A D D_{\text {ingestion }}}{R f D}
$$

$$
H I=\sum H Q_{\text {ingestion }}
$$

$$
C R=A D D_{\text {ingestion }} \times S F
$$

...where $H Q_{\text {ingestion }}$ was a hazard quotient and $H I$ is the hazard index. When $\mathrm{HI}>1$, the non-carcinogenic risk value brought by heavy metal elements should be considered [23]; RfD denotes daily average reference exposure dose $(\mu \mathrm{g} / \mathrm{kg} / \mathrm{d})$, in this study, 3 for $\mathrm{Cr}, 0.4$ for $\mathrm{Cd}, 20$ for $\mathrm{Ni}, 40$ for $\mathrm{Cu}, 300$ for $\mathrm{Zn}, 20$ for $\mathrm{V}, 3.6$ for $\mathrm{Pb}$, and 520 for $\mathrm{Mn}$ [26]; $S F$ was a carcinogenic slope factor $((\mathrm{mg} /(\mathrm{kg} \cdot \mathrm{d}))-1), 0.5$ for $\mathrm{Cr}$, and 0.38 for $\mathrm{Cd}$. 
Table 1. Statistical characteristic analysis of heavy metal contents in collapsed lake ( $\mu \mathrm{g} / \mathrm{L})$.

\begin{tabular}{|c|c|c|c|c|c|c|c|c|c|c|c|c|}
\hline & \multicolumn{3}{|c|}{ Spring } & \multicolumn{3}{|c|}{ Summer } & \multicolumn{3}{|c|}{ Autumn } & \multicolumn{3}{|c|}{ Winter } \\
\hline & Max. & Min. & Ave. & Max. & Min. & Ave. & Max. & Min. & Ave. & Max. & Min. & Ave. \\
\hline $\mathrm{V}$ & 4.93 & 1.80 & 3.35 & 7.04 & 2.66 & 4.51 & 4.78 & 3.00 & 3.87 & 5.25 & 1.88 & 3.13 \\
\hline $\mathrm{Cr}$ & 0.17 & 0.13 & 0.14 & 0.07 & 0.03 & 0.05 & 1.52 & 1.11 & 1.33 & 1.92 & 1.08 & 1.40 \\
\hline $\mathrm{Mn}$ & 2.44 & 0.22 & 0.80 & 1.47 & 0.23 & 0.71 & 0.23 & 0.12 & 0.17 & 1.79 & 0.36 & 0.98 \\
\hline $\mathrm{Ni}$ & 1.47 & 1.03 & 1.23 & 1.66 & 0.41 & 0.84 & 0.58 & 0.23 & 0.40 & 0.85 & 0.64 & 0.77 \\
\hline $\mathrm{Cu}$ & 0.88 & 0.13 & 0.45 & 1.29 & 0.36 & 0.79 & 0.42 & 0.27 & 0.34 & 0.75 & 0.37 & 0.54 \\
\hline $\mathrm{Zn}$ & 0.69 & 0.16 & 0.34 & 1.89 & 0.46 & 1.10 & 1.59 & 1.04 & 1.28 & 1.46 & 0.92 & 1.18 \\
\hline $\mathrm{Cd}$ & 0.02 & 0.001 & 0.01 & 0.06 & 0.02 & 0.04 & 0.05 & 0.02 & 0.03 & 0.05 & 0.03 & 0.03 \\
\hline $\mathrm{Pb}$ & 0.05 & 0.01 & 0.02 & 0.16 & 0.03 & 0.08 & 0.12 & 0.04 & 0.07 & 0.08 & 0.02 & 0.05 \\
\hline
\end{tabular}

\section{Results and Discussion}

\section{Seasonal Content Characteristics of Heavy Metals}

Predecessors have accumulated a lot of research results on the abundance and distribution characteristics of heavy metals [34-36 ]. First, the two collapsed lakes as a whole are described as the seasonal variation characteristics of their heavy metal concentrations (Table 1). The order of the average content of metal elements in lake water is spring: $\mathrm{V}>\mathrm{Ni}>$ $\mathrm{Mn}>\mathrm{Cu}>\mathrm{Cr}>\mathrm{Zn}>\mathrm{Pb}>\mathrm{Cd}$, summer: $\mathrm{V}>\mathrm{Zn}>\mathrm{Ni}>\mathrm{Cu}>\mathrm{Mn}>$ $\mathrm{Pb}>\mathrm{Cr}>\mathrm{Cd}$, autumn: $\mathrm{V}>\mathrm{Cr}>\mathrm{Zn}>\mathrm{Ni}>\mathrm{Cu}>\mathrm{Mn}>\mathrm{Pb}>\mathrm{Cd}$, and winter: $\mathrm{V}>\mathrm{Cr}>\mathrm{Zn}>\mathrm{Mn}>\mathrm{Ni}>\mathrm{Cu}>\mathrm{Pb}>\mathrm{Cd}$. It can be seen from the above that the order of the weight metal content of the collapsed lake water was different in each season. It was worth noting that $\mathrm{V}$ has the highest content in the four seasons, and $\mathrm{Cd}$ has the lowest content in the four seasons, reflecting that the content of these two elements was less affected by seasonal changes. The contents of $\mathrm{Ni}, \mathrm{Cu}$ and $\mathrm{Pb}$ elements were consistent in the four seasons, all of which are $\mathrm{Ni}>\mathrm{Cu}>\mathrm{Pb}$. The obvious seasonal difference was the $\mathrm{Cr}$ element, which is low in spring and summer, but it increases significantly in autumn and winter and was only lower than V. In addition, the average value of heavy metal content in spring and summer in the study area was compared with the water body in the collapsed area of Panyi Coal Mine in Huainan, $150 \mathrm{~km}$ away. The order of the metal element mean content is spring: $\mathrm{Cu}>\mathrm{Pb}>\mathrm{Cd}>\mathrm{Cr}>\mathrm{Ni}>\mathrm{Zn}$ [37] and summer: $\mathrm{Mn}>\mathrm{Zn}>\mathrm{Cu}>\mathrm{Ni}>\mathrm{Cr}>\mathrm{Pb}>\mathrm{Cd}$ [38]. Comparison showed that the order of heavy metal content in spring and summer in Huainan collapsed lake was significantly different from that in the study area. And high content difference of $\mathrm{Cu}, \mathrm{Pb}, \mathrm{Mn}$ and other elements may be related to the mixing of industrial and domestic wastewater in the surface river (Ni River) of Panyi Coal Mine.

Secondly, we compared the seasonal differences in heavy metal content between the two collapsed lakes. In Fig. 2, the left side of the red dotted line is collapsed lake-I $(C L-I)$, and the right side is collapsed lake-II

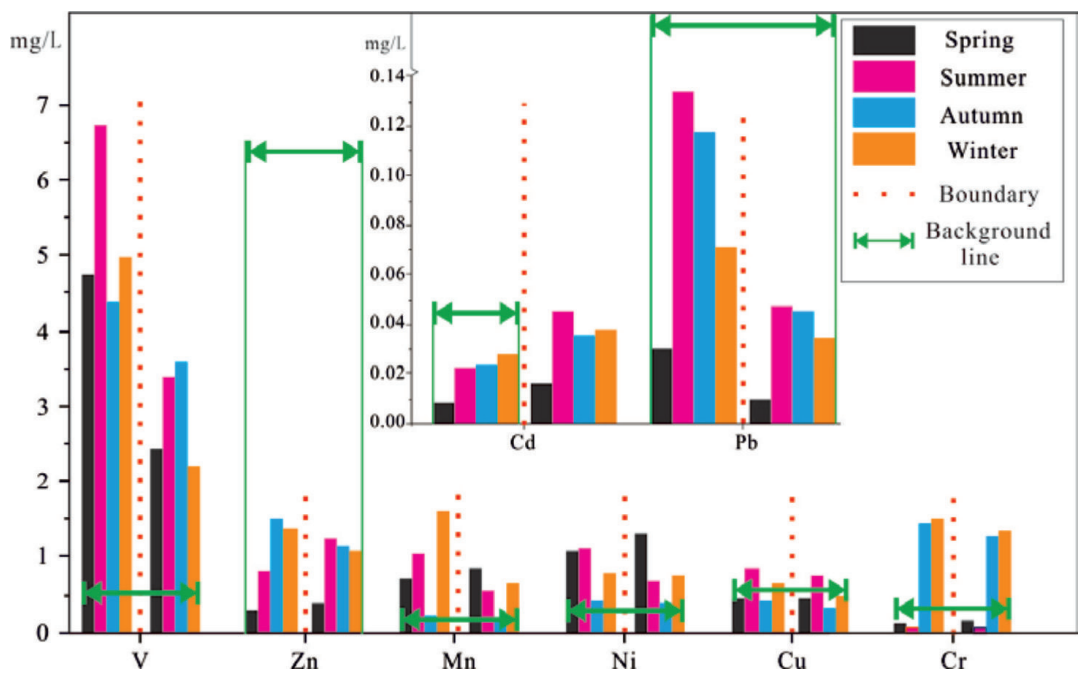

Fig. 2. Seasonal comparison of the average heavy metal contents in two collapsed lakes. 
Table 2. Correlation matrix of eight heavy metals.

\begin{tabular}{|c|c|c|c|c|c|c|c|c|}
\hline & $\mathrm{V}$ & $\mathrm{Cr}$ & $\mathrm{Mn}$ & $\mathrm{Ni}$ & $\mathrm{Cu}$ & $\mathrm{Zn}$ & $\mathrm{Cd}$ & $\mathrm{Pb}$ \\
\hline $\mathrm{V}$ & 1 & & & & & & & \\
\hline $\mathrm{Cr}$ & -0.463 & 1 & & & & & & \\
\hline $\mathrm{Mn}$ & 0.171 & -0.51 & 1 & & & & & \\
\hline $\mathrm{Ni}$ & 0.4 & -0.486 & $\mathbf{0 . 6 5 3}$ & 1 & & & & \\
\hline $\mathrm{Cu}$ & 0.155 & $\mathbf{- 0 . 6 9 3}$ & 0.224 & 0.46 & 1 & & & \\
\hline $\mathrm{Zn}$ & -0.391 & 0.183 & -0.589 & $\mathbf{- 0 . 6 9 7}$ & -0.222 & 1 & & \\
\hline $\mathrm{Cd}$ & -0.433 & -0.049 & -0.375 & -0.372 & 0.25 & 0.253 & 1 & \\
\hline $\mathrm{Pb}$ & 0.244 & -0.096 & -0.348 & -0.546 & -0.28 & 0.456 & -0.169 & 1 \\
\hline
\end{tabular}

Correlation of variables in bold is greater than 0.6

$(C L-I I)$. For heavy metals $(\mathrm{V}, \mathrm{Cr}, \mathrm{Mn}, \mathrm{Cu}, \mathrm{Zn}, \mathrm{Pb})$, content comparison is: $C L-I>C L-I I$. For heavy metals $(\mathrm{Ni}, \mathrm{Cd})$, content comparison is: $C L-I I>C L-I$. On the whole, the heavy metal content of the $C L-I$ was higher than that of the $C L-I I$, which may be related to the surrounding area of the collapsed lake-I, which is affected by domestic sewage or garbage. In terms of the trend of heavy metal seasons, the two collapsed lakes have higher consistency (Fig. 2). For example, for $\mathrm{V}$ and $\mathrm{Pb}$ the trend of change is increased in autumn and winter in spring and summer; on the contrary, the trend of $\mathrm{Cr}$ changes in spring and summer to decrease in autumn and winter, while the trend of $\mathrm{Cd}$ content in seasons increases gradually, because the metal content of the two collapsed lakes was much lower than the drinking water quality guidance issued by the World Health Organization (WHO) in 2011 and the groundwater national standard announced by the National Quality Supervision Bureau in 2017 [39-40]. The Yangtze River was selected as the area providing background values in the study [41]. Fig. 2, the elements of the above background value are $\mathrm{V}$ and $\mathrm{Ni}$, and partly $\mathrm{Cd}, \mathrm{Cr}, \mathrm{Cu}$ and $\mathrm{Pb}$. Among them, the background value of $\mathrm{V}$ in the four collapsed lakes is 8.45 12.93 and 4.23 6.54. It is worth noting that the $\mathrm{Cr}$ content was lower than the background value in spring and summer, and about 3.7 times higher than the background value in autumn and winter.

\section{Heavy Metal Element Source Analysis}

PCA was often used to understand the correlation and source of various heavy metal elements in water [42]. From the above, regarding the four seasons of heavy metals in the two water bodies, the changes were more consistent, so the heavy metal source analysis was carried out as a whole. Determining the correlation of each heavy metal was a necessary step before the data was subjected to principal component analysis. The correlation of heavy metal elements after "logarithmic" pretreatment is mostly greater than 0.3 (Table 2).
Studies had shown that when the correlation of most variables was greater than 0.3 , the results of principal component analysis were more reliable [43].

Three principal components (PCs) (Fig. 3) were extracted from eight heavy metal elements, which together account for $81.6 \%$ of the variance contribution rate, so they were used to discuss the sources of each heavy metal. The variance contribution rate of principal components 1 (PC1) was $42.3 \%$, and the high load variables were $\mathrm{Mn}$ and $\mathrm{Ni}$. The source was mainly soil formation and rock weathering. In addition, the first principal component of the variable was often related to human activities, so coal resource combustion, automobile exhaust and industrial waste emissions were the sources of the siderophile elements $\mathrm{Mn}$ and $\mathrm{Ni}$ [44]. The variance contribution rate of principal components 2 (PC2) was 20.6\%, and the high load variables were $\mathrm{Pb}$ and $\mathrm{V}$. Combined with the $\mathrm{V}$ element content in

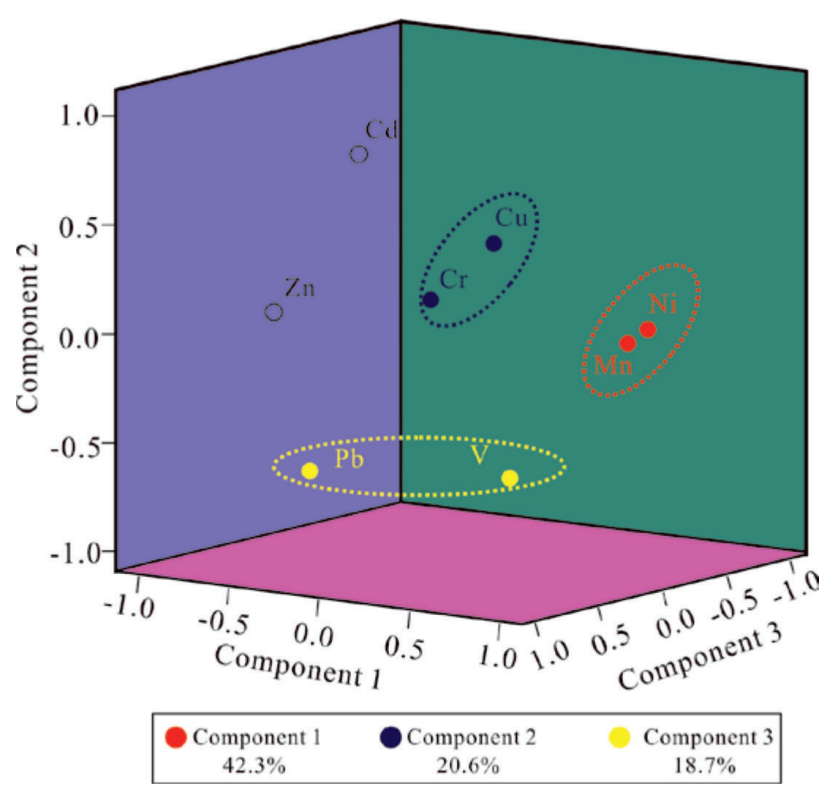

Fig. 3. Principal component analysis (PCA) for dissolved heavy metals in collapsed lakes. 
Table 3. Carcinogenic and non-carcinogenic risk values of heavy metals in the intake pathway.

\begin{tabular}{|c|c|c|c|c|c|c|c|c|}
\hline \multirow[t]{2}{*}{ Risk } & \multicolumn{2}{|c|}{$\begin{array}{c}\text { Spring } \\
(\mathrm{N}=10)\end{array}$} & \multicolumn{2}{|c|}{$\begin{array}{c}\text { Summer } \\
(\mathrm{N}=6)\end{array}$} & \multicolumn{2}{|c|}{$\begin{array}{c}\text { Autumn } \\
(\mathrm{N}=6)\end{array}$} & \multicolumn{2}{|c|}{$\begin{array}{l}\text { Winter } \\
(\mathrm{N}=6)\end{array}$} \\
\hline & Adult & Child & Adult & Child & Adult & Child & Adult & Child \\
\hline \multicolumn{9}{|c|}{ Carcinogenic $\operatorname{Risk}(C R)^{\mathrm{a}}$} \\
\hline $\mathrm{Cr}$ & 5.38E-08 & $5.62 \mathrm{E}-08$ & $1.71 \mathrm{E}-08$ & $1.79 \mathrm{E}-08$ & 4.99E-07 & $5.22 \mathrm{E}-07$ & $5.28 \mathrm{E}-07$ & $5.51 \mathrm{E}-07$ \\
\hline $\mathrm{Cd}$ & $1.88 \mathrm{E}-08$ & $1.96 \mathrm{E}-08$ & $5.46 \mathrm{E}-08$ & $5.70 \mathrm{E}-08$ & $4.55 \mathrm{E}-08$ & $4.76 \mathrm{E}-08$ & $5.03 \mathrm{E}-08$ & $5.25 \mathrm{E}-08$ \\
\hline \multicolumn{9}{|c|}{ Hazard Quotient $(H Q)^{\mathrm{a}}$} \\
\hline $\mathrm{Cr}$ & $8.38 \mathrm{E}-05$ & $8.75 \mathrm{E}-05$ & $2.67 \mathrm{E}-05$ & $2.79 \mathrm{E}-05$ & 7.77E-04 & $8.11 \mathrm{E}-04$ & $8.21 \mathrm{E}-04$ & $5.15 \mathrm{E}-03$ \\
\hline $\mathrm{Cd}$ & $2.88 \mathrm{E}-04$ & $3.01 \mathrm{E}-04$ & $8.38 \mathrm{E}-04$ & $8.75 \mathrm{E}-04$ & $6.99 \mathrm{E}-04$ & $7.30 \mathrm{E}-04$ & $7.72 \mathrm{E}-04$ & 4.84E-03 \\
\hline $\mathrm{Mn}$ & $5.73 \mathrm{E}-08$ & $2.82 \mathrm{E}-06$ & 5.07E-08 & $2.49 \mathrm{E}-06$ & $1.25 \mathrm{E}-08$ & $6.15 \mathrm{E}-07$ & $7.00 \mathrm{E}-08$ & $2.06 \mathrm{E}-05$ \\
\hline $\mathrm{Ni}$ & $3.16 \mathrm{E}-04$ & $3.30 \mathrm{E}-04$ & $2.16 \mathrm{E}-04$ & $2.26 \mathrm{E}-04$ & $1.04 \mathrm{E}-04$ & $1.08 \mathrm{E}-04$ & $1.99 \mathrm{E}-04$ & $1.25 \mathrm{E}-03$ \\
\hline $\mathrm{Cu}$ & $1.96 \mathrm{E}-03$ & $2.04 \mathrm{E}-03$ & $3.47 \mathrm{E}-03$ & $3.62 \mathrm{E}-03$ & $1.49 \mathrm{E}-03$ & $1.56 \mathrm{E}-03$ & $2.37 \mathrm{E}-03$ & $1.48 \mathrm{E}-02$ \\
\hline $\mathrm{Zn}$ & $5.76 \mathrm{E}-06$ & $6.02 \mathrm{E}-06$ & $1.88 \mathrm{E}-05$ & $1.97 \mathrm{E}-05$ & $2.20 \mathrm{E}-05$ & $2.30 \mathrm{E}-05$ & $2.03 \mathrm{E}-05$ & $1.27 \mathrm{E}-04$ \\
\hline V & 4.97E-05 & $5.19 \mathrm{E}-05$ & $6.68 \mathrm{E}-05$ & $6.98 \mathrm{E}-05$ & $5.73 \mathrm{E}-05$ & $5.98 \mathrm{E}-05$ & 4.64E-05 & $2.91 \mathrm{E}-04$ \\
\hline $\mathrm{Pb}$ & $2.65 \mathrm{E}-05$ & $2.77 \mathrm{E}-05$ & $1.13 \mathrm{E}-04$ & $1.18 \mathrm{E}-04$ & $1.04 \mathrm{E}-04$ & $1.08 \mathrm{E}-04$ & $7.04 \mathrm{E}-05$ & 4.41E-04 \\
\hline$H I^{\mathrm{a}}$ & $2.73 \mathrm{E}-03$ & $4.75 \mathrm{E}-03$ & $3.26 \mathrm{E}-03$ & 4.29E-03 & $2.85 \mathrm{E}-03$ & $4.96 \mathrm{E}-03$ & $3.40 \mathrm{E}-03$ & $2.69 \mathrm{E}-02$ \\
\hline
\end{tabular}

Note: $N$-samples; ${ }^{a}$ means $C R, H Q, H I$ were average value of water samples.

Fig. 2, the source of analysis was industrial and domestic combustion of coals [45]. The variance contribution rate of principal components 3 (PC3) was $18.7 \%$, and the high load variables were $\mathrm{Cr}$ and $\mathrm{Cu}$. Studies have shown that there was a good spatial-temporal correlation between $\mathrm{Cr}$ and $\mathrm{Cu}$ in the soil of the mining area [46]. In combination with the content of $\mathrm{Cr}$ and $\mathrm{Cu}$ in Fig. 2, the consistent variation characteristics of the two collapsed lakes were consistent. It was speculated that the source of $\mathrm{Cr}$ was consistent with the source of $\mathrm{Cu}$, which is affected by natural factors. It is speculated that the seasonal characteristics of $\mathrm{Cr}$ content in Fig. 2 may be related to the following: (1) atmospheric precipitation in the study area mainly exists in spring and summer, and atmospheric precipitation dilutes $\mathrm{Cr}$ in water and (2) spring and summer are the seasons for the growth of fry and phytoplankton. $\mathrm{Cr}$ is adsorbed into the fish or plant by the suspended matter in the water. Less fish eating and phytoplankton death in autumn and winter increases the $\mathrm{Cr}$ content in water.

\section{Risk Assessment}

\section{Non-Carcinogenic Risk}

Hazard quotient $(H Q)$ was introduced to characterize the non-carcinogenic health risks of 8 heavy metals in humans under the intake route. Table 3 shows that children are exposed to health risks greater than adults in all four seasons. It should be noted that in winter lake water, the risk to children with $\mathrm{Cr}$ and $\mathrm{Cd}$ was higher, the values were: 5.15E-03, 4.84E-03, and children harmed by Mn was 49.21 times that of adults (Table 3). Overall, the non-carcinogenic risks of heavy metals were ranked as follows: $\mathrm{Cu}>\mathrm{Cd}>\mathrm{Cr}>\mathrm{Ni}>\mathrm{Pb}$ $>\mathrm{V}>\mathrm{Zn}>\mathrm{Mn}$.

In terms of seasonal changes, the health risks of heavy metals in winter were highest. For example, the risk of $\mathrm{Cu}$ in adults and children in winter is 2.37E-03 and 1.48E-02 respectively. Secondly, the summer and winter health risks were greater than spring and autumn. This phenomenon was common in the two lakes, such as $\mathrm{Cr}, \mathrm{Mn}, \mathrm{Ni}$, and $\mathrm{V}$.

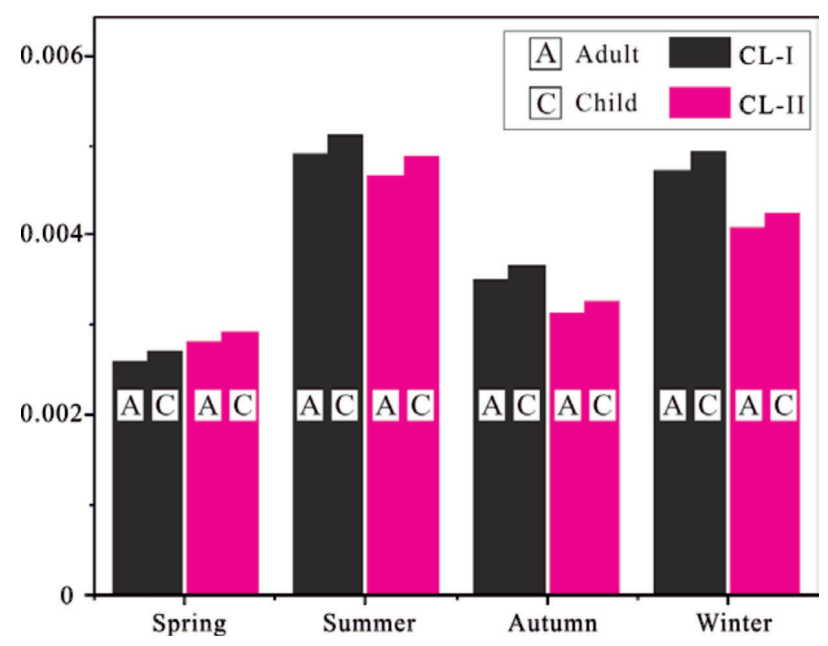

Fig. 4. Non-carcinogenic health risk assessment of two collapsed lakes in the study area. 
Fig. 4 shows the seasonal mean hazard index $(H I)$ for two lakes. Except for spring, the $H I$ value of the $C L-I$ in the other three seasons was higher than that of the $C L-I I$ (Fig. 4), reflecting the higher overall health risk of the $C L-I$, which is consistent with the discussion in Fig. 2. Secondly, the summer health risk was the biggest and the spring is the smallest, which is related to the difference in the content of each heavy metal in the four seasons.

Generally, the $H I$ values of the two lakes are less than 1, which means that the non-carcinogenic risk caused by heavy metals is lower [23]. However, due to the persistence and toxicity accumulation of heavy metals, the potential non-carcinogenic health risks in lake water such as $\mathrm{Cu}, \mathrm{Cd}, \mathrm{Cr}$ and $\mathrm{Ni}$ increase with time.

\section{Carcinogenic Risk}

$\mathrm{Cr}$ and $\mathrm{Cd}$ were chemical carcinogens in this study. $\mathrm{Cr}$ and $\mathrm{Cd}$ had different carcinogenic health risks $(C R)$ in adult and children through the intake of fish. In the exposed population, children were at higher carcinogenic risk than adults in four seasons (Fig. 5) [47].

On the time scale, there were different major carcinogenic risk heavy metals in different seasons. The factor for high carcinogenic risk in spring, autumn and winter was $\mathrm{Cr}$, and $\mathrm{Cd}$ in summer. Specifically, unlike the non-carcinogenic risk of $\mathrm{Cr}$, the seasonal order of $\mathrm{Cr}$ carcinogenic risk was: winter $>$ autumn $>$ spring $>$ summer. The carcinogenic risk value of $\mathrm{Cd}$ was affected by high content in summer (Fig. 2), and the order was: summer $>$ winter $>$ autumn $>$ spring. On a spatial scale, carcinogenic risk caused by $\mathrm{Cr}$ in $C L-I$ in summer, autumn and winter was higher than that in $C L-I I$. In four seasons, carcinogenic risk caused by $\mathrm{Cd}$ in $C L-I I$ was higher than that of $C L-I$.

At the level of carcinogenic risk, the carcinogenic risk of $\mathrm{Cr}$ was higher than that of $\mathrm{Cd}$, which is consistent in three seasons (excluded summer) (Fig. 5). For adults and children, the carcinogenic risk range of $\mathrm{Cr}$ was 7.22E-07 1.16E-08; 7.54E-07 1.21E-08, and the range of $\mathrm{Cd}$ was 9.22E-08 1.31E-09; 9.63E-08 1.36E-09. It can be seen from the above that $\mathrm{Cr}$ is the main carcinogenic risk element in lake water, which is consistent with the main carcinogenic elements of shallow groundwater in the study area. Therefore, it is speculated that the lake water has a recharge relationship with shallow groundwater [18]. Finally, the maximum acceptable risk (1E06) recommended by the Swedish Environmental Protection Agency was selected as the reference standard [48]. The results showed that the carcinogenic risk of all water samples in the two lakes is currently below the warning line (1E-06), but the cumulative carcinogenic risk of $\mathrm{Cr}$ needed attention. Therefore, we can take some water treatment measures to change the occurrence of high content of heavy metal elements in water [49-50].

\section{Uncertainty Analysis}

A comprehensive health risk assessment should include health risks in three ways: intake, skin contact, and respiratory inhalation. This study evaluated the health risks of eight heavy metal elements in water based on the intake route. Uncertainty factors still exist in this study, such as: (1) water area of the collapsed lake is large, and the health risks of heavy metals passing through the respiratory inhalation route are not considered; (2) heavy metal types are not comprehensive enough, resulting in health risk calculations less than actual results; and (3) due to the lack of background parameters in the study area, the model parameters used in the paper are all from the US Environmental Protection Agency (except for a small number of parameters). In summary, this paper links the use of lake water with the way that heavy metals are most likely to enter the human body (fish intake), which

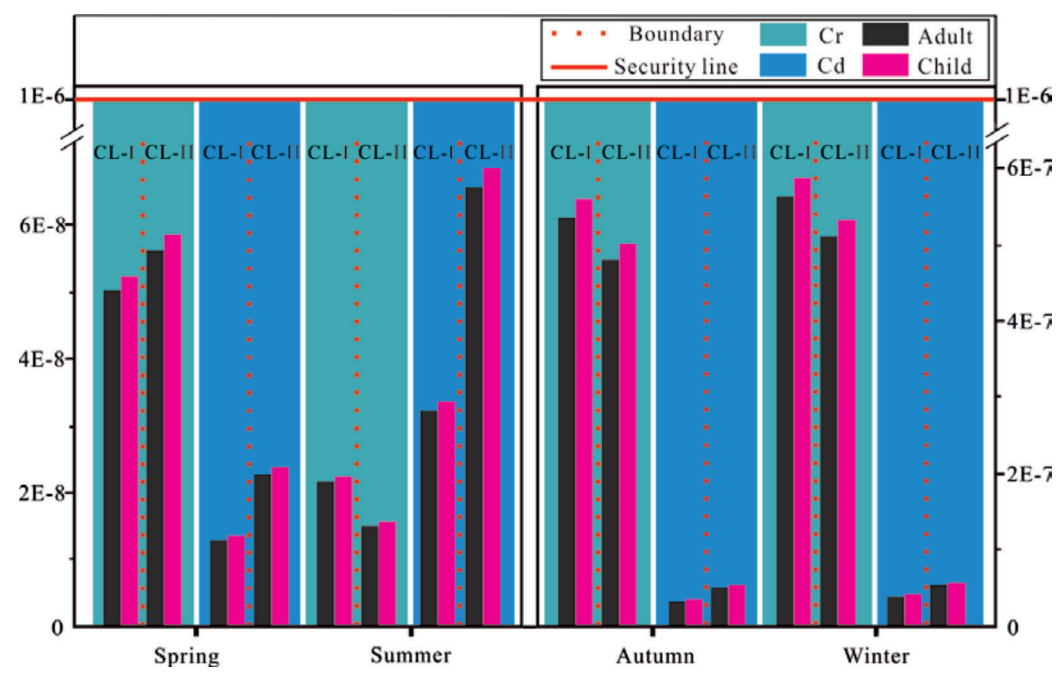

Fig. 5. Carcinogenic health risk assessment of $\mathrm{Cr}$ and $\mathrm{Cd}$ in two collapsed lakes in the study area. 
can provide a reference for related research by scholars in other regions.

\section{Conclusions}

Two collapsed lakes in Zhuxianzhuang Mine of Huaibei Coalfield were taken as examples. Twentyeight lake water samples were taken in spring, summer, autumn and winter, and 8 heavy metals $(\mathrm{V}, \mathrm{Cr}, \mathrm{Ni}, \mathrm{Cu}$, $\mathrm{Zn}, \mathrm{Mn}, \mathrm{Cd}$, and $\mathrm{Pb}$ ) in lake water were measured by ICP-MS. The difference of heavy metal content in each season was as follows - spring: $\mathrm{V}>\mathrm{Ni}>\mathrm{Mn}>\mathrm{Cu}>\mathrm{Cr}>$ $\mathrm{Zn}>\mathrm{Pb}>\mathrm{Cd}$, summer: $\mathrm{V}>\mathrm{Zn}>\mathrm{Ni}>\mathrm{Cu}>\mathrm{Mn}>\mathrm{Pb}>\mathrm{Cr}>\mathrm{Cd}$, autumn: $\quad \mathrm{V}>\mathrm{Cr}>\mathrm{Zn}>\mathrm{Ni}>\mathrm{Cu}>\mathrm{Mn}>\mathrm{Pb}>\mathrm{Cd}$, and winter: $\mathrm{V}>\mathrm{Cr}>\mathrm{Zn}>\mathrm{Mn}>\mathrm{Ni}>\mathrm{Cu}>\mathrm{Pb}>\mathrm{Cd}$. In addition, taking the Yangtze River water source area as the background value of the element, the main super-background values were: $\mathrm{V}, \mathrm{Ni}, \mathrm{Cu}, \mathrm{Cr}$, and the $\mathrm{V}$ content exceeds the background value multiple of 4.3 12.93.

Principal component analysis method was applied to the analysis of the source of heavy metal elements in the lake water, and the contribution rate of the three principal components extracted was $81.6 \%$. Coal resource combustion, automobile exhaust and industrial waste emissions were sources of $\mathrm{Mn}$ and Ni. Highcontent element V source was mining or fossil energy burning. Because of the good space-time correlation between $\mathrm{Cr}$ and $\mathrm{Cu}$, it was speculated that $\mathrm{Cr}$ and $\mathrm{Cu}$ have the same source, which are affected by natural factors.

Eight heavy metal elements were used as chemical non-carcinogens, and $\mathrm{Cr}$ and $\mathrm{Cd}$ were chemical carcinogens. The most common exposure pathways for heavy metals into the human body (fish intake route) were determined, and the risk of non-carcinogenic and carcinogenic health of the lake water was calculated. The results show that the HI of the lake is less than 1, namely the non-carcinogenic risk caused by heavy metal elements was still within the safety line. Secondly, the non-carcinogenic risk of adults and children brought about by 8 heavy metals was consistent. The change of hazard quotient was: $\mathrm{Cu}>\mathrm{Cd}>\mathrm{Cr}>\mathrm{Ni}>\mathrm{Pb}>\mathrm{V}>\mathrm{Zn}>\mathrm{Mn}$. Among the carcinogenic factors, $\mathrm{Cr}$ was the main carcinogenic risk element in lake water, and the risk value varies from 1.16E08 to 7.54E-07, which has not exceeded the maximum acceptable risk range (1E-06). Among the exposed population, children were more threatened by health risks than adults. Among them, Mn has a child risk quotient of 49.21 times that of adults. Finally, there were differences in health risks in different seasons. Overall, spring health risks were lowest and winters are highest.

In summary, although the risk of human health caused by ingestion of food in water is still within the safe range, the health risk values of elements such as $\mathrm{Cu}$ and $\mathrm{Cr}$ show that they are getting closer to the safety line. From the perspective of public health and safety, we need to maintain further observation and research on these elements.

\section{Acknowledgements}

We sincerely thank the editors and peer reviewer for their work in improving the quality of our article.

\section{Funding}

This article is funded by the National Natural Science Foundation of China (41773100, 41373095), a research project of Wanbei Coal-Electricity Group Co. Ltd (2019) and a research project of Huaibei Mining Group Co. (2019).

\section{Conflicts of Interest}

The authors declare no conflict of interest.

\section{References}

1. SAINI V., GUPTA R.P., ARORA M.K. Environmental impact studies in coalfields in India: A case study from Jharia coal-field. Renew. Sust, Renewable and Sustainable Energy Reviews, 53, 1222, 2016.

2. PECZULA W., SZCZUROWSKA A., PONIEWOZIK M. Phytoplankton community in early stages of reservoir development-a case study from the newly formed, colored, and episodic lake of mining-subsidence genesis. Polish Journal of Environmental Studies, 23 (2), 585, 2014.

3. JUNIAH R., DALIMI R., SUPARMOKO M., MOERSIDIK S.S., WARISTIAN H. Environmental value losses as impacts of natural resources utilization of in coal open mining. Sriwijaya International Conference On Engineering, Sinence and Technology, 101, 2017.

4. MOSKOVAYA I.V., OLISHEVSKIY A.T., LAZAREVA L.P. Assessment of efficiency of windbreak and dust suppression walls for coal terminals. Environmental Earth Sciences, 87, 2017.

5. ZHANG X., YU H., DONG J.Y., LIU S., HUANG Z., WWANG J., WONG H. A physical and numerical model-based research on the subsidence features of overlying strata caused by coal mining in Henan, China. Environmental Earth Sciences, 705, 2017.

6. MACHOWSKI R., RZETALA M.A., RZETALA M., SOLARSKI M. Geomorphological and hydrological effects of subsidence and land use change in industrial and urban areas. Land Degradation \& Development, 27 (7), 1740, 2016.

7. LI F.M. Current situation and development trend of mining subsidence area management technology in China. Coal Mining Technology, 16 (3), 8, 2011.

8. ZHANG B., ZHENG X.L., ZHENG T.Y., XIN J., SUI S., ZHANG D. The influence of slope collapse on water exchange between a pit lake and a heterogeneous aquifer. Frontiers of Environmental Science \& Engineering, 13 (2), 20, 2019. 
9. XIA Y.T., GUI H.R., ZHAO H.H., LI J., GUAN L.S. Temporal vartability of hydro-chemical characteristics and water quality assessment of collapse pond in Zhuxianzhuang coal mining area, China. Fresenius Environmental Bulletin, 28 (1), 402, 2019.

10. IQBAL M. Vicia faba bioassay for environmental toxicity monitoring: A review. Chemosphere 144, 785, 2016.

11. ABBAS M., ADIL M., EHTISHAM-UL-HAQUE S., MUNIR B., YAMEEN M., GHAFFAR A., SHAR G.A., ASIF TAHIR M., IQBAL M. Vibrio fischeri bioluminescence inhibition assay for ecotoxicity assessment: A review. Science of The Total Environment 626, 1295, 2018.

12. IQBAL M., ABBAS M., NAZIR A., QAMAR A.Z. Bioassays based on higher plants as excellent dosimeters for ecotoxicity monitoring: A review. Chemistry International, 5, 1, 2019.

13. CHEN G.Z., WANG X.M., WANG R.W. Health risk assessment of potentially harmful elements in subsidence water bodies using a Monte Carlo approach: An example from the Huainan coal mining area, China. Ecotoxicology and Environmental Safety, 171, 737, 2019.

14. XIE K., ZHANG Y., YI Q.T., YAN J.P. Optimal resource utilization and ecological restoration of aquatic zones in the coal mining subsidence areas of the Huaibei Plain in Anhui Province, China. Desalination and Water Treatment, 51 (19-21), 4019, 2013.

15. JIANG J.D. Study on Optimization of Different Utilization Modes of Reclaimed Subsided Land in Coal Mining Areas - A Case Study of Zhuxianzhuang Coal Mining Area. China university of mining and technology, 2014.

16. QI W.Q,. LIAN J., SUN Z.G. Technical Explanations for - Technical Specifications Requirements for Monitoring of Surface Water and Waste Water - (HJ T91 -2002). Environmental Monitoring in China, 22 (1), 54, 2006.

17. GUAN L.S., GUI H.R., KANG Z.Y., ZHAO H.H., Li J. Hydrochemiacl characteristics and water quality assessment in goaf water of Kouquangou mining area in Datong, Shanxi, China. Fresenius Environmental Bulletin, 27 (12A), 9315, 2018.

18. QIU H.L., GUI H.R. Heavy metals contamination in shallow groundwater of a coal-mining district and a probabilistic assessment of its human health risk. Human and Ecological Risk Assessment, 25 (3), 548, 2019.

19. MWAKALAPA E.B., SIMUKOKO C.K., MMOCHI A.J., MAO C.P., SONG Y.X., CHEN LX., JI J.F., LI J.Z., YUAN X.Y., YANG ZF., AYOKO G.A., FROST R.L., THEISS F. Heavy metals in farmed and wild milkfish (Chanos chanos) and wild mullet (Mugil cephalus) along the coasts of Tanzania and associated health risk for humans and fish. Chemosphere, 175, 339, 2019.

20. KAVCAR P., SOFUOGLU A., SOFUOGLU S.C. A health risk assessment for exposure to trace metals via drinking water ingestion pathway, International journal of hygiene and environmental health, 212 (2), 216, 2009.

21. JIANG L., ZHONG M.S., JIA X.Y., XIA T.X., YAO J.J., FAN Y.L., ZHANG L.N., TANG Z.Q. Case study on groundwater health risk assessment and remediation strategy based on exposure pathway. Huan Jing Ke Xue, 33 (10), 3329, 2012.

22. DICKIN S.K., SCHUSTERr-WALLACE C.J., MANZOOR Q.,PIZZACALLA K. A Review of Health Risks and Pathways for Exposure to Wastewater Use in Agriculture. Environmental Health Perspectives, 124 (7), 900, 2016.

23. US Environmental Protection Agency (USEPA). Risk Assessment Guidance for Superfund Volume 1. Human
Health Evaluation Manual (Part E, Supplemental Guidance for Dermal Risk Assessment). EPA/540/R/99/005 Office of Superfund Remediation and Technology Innovation; U.S. Environmental Protection Agency, Washington, DC, 2004.

24. US Environmental Protection Agency (USEPA). "Water Quality Criteria Documents; Availability". Federal Register Washington DC, 45 (231), 79318, 1980.

25. JACOBS H.L., KAHN H.D., STRALKA K.A., PHAN D.B. Estimates of per Capita Fish Consumption in the U.S. Based on the Continuing Survey of Food Intake by Individuals (CSFII). Risk analysis : an official publication of the Society for Risk Analysis, 18 (3), 283, 1998.

26. US Environmental Protection Agency (USEPA). Superfund Public Health Evaluation Manual. Washington DC, 1986.

27. ZENG Y.Y., LAI Z.N., GU, B.H., YANG W.L., GAO Y., WANG C., LI Y.F. Heavy metal accumulation patterns in tissues of Guangdong bream (Megalobrama terminalis) from the Pearl River, China. Fresenius Environmental Bulletin, 23 (3A), 851, 2014.

28. US Environmental Protection Agency (USEPA). Quantitative Uncertainty Analysis of Superfund Residential Risk Pathway Models for Soil and Groundwater: White Paper, 1996.

29. GIRI S., SINGH A.K. Human health risk assessment via drinking water pathway due to metal contamination in the groundwater of Subarnarekha River Basin, India. Environmental Monitoring and Assessment, 187 (3), 2015.

30. IQBAL J., SHAH M.H. Study of seasonal variations and health risk assessment of heavy metals in Cyprinus carpiofrom Rawal Lake, Pakistan. Environmental Monitoring and Assessment, 186 (4), 2025, 2014.

31. BAKSHI S., ZHANG X., GODIY-TUNDIDOR S., CHENG R.Y.S., SARTOR M.A., MEDVEDOVIC M., HO S.M. Transcriptome Analyses in Normal Prostate Epithelial Cells Exposed to Low-Dose Cadmium: Oncogenic and Immunomodulations Involving the Action of Tumor Necrosis Factor. Environmental Health Perspectives, 116 (6), 769, 2008.

32. US Environmental Protection Agency (USEPA). International Risk Information System (IARC). Available online: http://cfpub.epa.gov/ncea/iris/index.cfm? fuseaction=iris. ShowSubstanceList, 2013.

33. LIN M.L., GUI H.R., PENG W.H., SUN L.H., CHEN S. Health risk assessment of heavy metals in deep groundwater from different aquifers of a typical coal mining area: A case study of a coal mining area in Northern Anhui Province. Hydrogeology \& Engineering Geology, 35 (5), 589, 2014.

34. SIDDIQUE A., HASSAN A., KHAN S., INAYAT A., NAZIR A. Appraisal of heavy metals and nutrients from phosphate rocks, Khyber Pakhtunkhwa, Pakistan. Chemistry International, 4, 1, 2018.

35. FAIT S., SAID F., EL MZIBRI M., FAIZ Z., FOUGRACH., BADRI W., SMOUNI A., FAHR M. Distribution of metallic trace elements (ETM) in surface soils around the mediouna discharge (southern of Casablanca). Chemistry International, 3, 278, 2017.

36. CHIDI O., KELVIN R. Surface interaction of sweet potato peels (Ipomoea batata) with $\mathrm{Cd}$ (II) and $\mathrm{Pb}$ (II) ions in aqueous medium. Chemistry International 4, 221, 2018.

37. CHEN J., DONG S.C., YIN H.W., REN Y.L., YAO S.P. Health risk assessment of water environment of coal mining subsidence area in Panyi coal mine of Huainan. Coal Geology \& Exploration, 45 (4), 118, 2017. 
38. REN Y.L., DONG S.C., YAO S.P. Spatial distribution characteristics of heavy metals in Huainan subsidence pond. Coal Geology \& Exploration, 46 (1), 125, 2018.

39. Word Health Organization (WHO). Guidelines for drinking water quality, 4nd edition, Geneva, 2011.

40. Bureau of Quality and Technical Supervision of China (BQTS). National standard of the people's republic of China: quality standard for groundwater (GB/T 148482017). Beijing: Standards Press of China, 2017.

41. ZHANG L.C. Geochemistry of water environment in the source area of Yangtze river. China Environmental Science Press, 1992.

42. WANG C.L., WU C., WANG W.J. Application of synthetic principal component analysis model to mine area farmland heavy metal pollution assessment. Journal of Coal Science and Engineering (China), 14(1), 109, 2008.

43. LIU B. Research on the supply evaluation of China's mega cities based on principal component analysis. China University of Political Science and Law, 2009.

44. XIAO J., WANG L., DENG L., JIN Z.D. Characteristics, sources, water quality and health risk assessment of trace elements in river water and well water in the Chinese Loess Plateau. Science of The Total Environment, 650, 2004, 2019.

45. BASHA S., JHALA J., THORAT R., GOEL S., TRIVEDI R., SHAH K., MENON G., GAUR P., MODY K.H., JHA B. Assessment of heavy metal content in suspended particulate matter of coastal industrial town, Mithapur Gujarat, India. Atmospheric Research, 97 (1-2), 257, 2010.

46. GUO M.X. Research on Spatial Distribuyion and Contamination Sources of Heavy Metals of $\mathrm{Cu}, \mathrm{Ni}$, As, $\mathrm{Zn}$ and $\mathrm{Cr}$ in Huainan Mining Area Based on GIS. Hefei University of Technology, 2016.

47. MAJOLAGBE A., OKETOLA A., OSIBANJO O., ADAMS A., OJURI O. Pollution vulnerability and health risk assessment of groundwater around an engineering Landfill in Lagos, Nigeria. Chemistry International, 3, 58, 2017.

48. CHE F. Human health risk assessment of heavy metal in multimedia environment in Shen-Fu Irrigation Area in Liaoning province. Chinese academy of environmental sciences, 2009.

49. LEGROURI K., KHOUYA E., HANNACHE H., El HARTTI M., EZZINE1 M., NASLAIN R. Activated carbon from molasses efficiency for $\mathrm{Cr}(\mathrm{VI}), \mathrm{Pb}(\mathrm{II})$ and $\mathrm{Cu}(\mathrm{II})$ adsorption: A mechanistic study. Chemistry International, 3 (3), 2017.

50. DJEHAF K., BOUYAKOUB A.Z., OUHIB R., BENMANSOUR H., ALI B., MAHDAD A., MOULAY N., DJILLALI B., AMERI M. Textile wastewater in Tlemcen (Western Algeria): Impact, Treatment by combined process. Chemistry International, 3 (4), 314, 2017. 